\title{
Inhibition of ovulation in PMSG/hCG-treated immature rats by rotenone, a specific inhibitor of mitochondrial oxidation
}

\author{
M. Koshida, A. Takenaka*, H. Okamura† and T. Mori
}

Department of Gynecology and Obstetrics, Kyoto University Faculty of Medicine, Kyoto, Japan; * Department of Obstetrics and Gynecology, Shiga University of Medical Science, Otsu, Japan and $\dagger$ Department of Obstetrics and Gynecology, Kumamoto University Medical School, Kumamoto, Japan

\begin{abstract}
Summary. Immature Wistar rats were induced to ovulate by treatment with PMSG and hCG. Control animals ovulated $43.5 \pm 0.36$ ova/rat. Intraperitoneal injection of rotenone doses of $0.125,0.25$ and $0.50 \mathrm{mg} / \mathrm{kg}$ reduced the ovulation rate to $24.0 \pm 3.08$, $8 \cdot 0 \pm 0.88$ and $1.5 \pm 0.44$ ova/rat, respectively. The rotenone significantly reduced ovarian cytochrome oxidase activity and progesterone production, but not production of oestradiol or testosterone. Thyroxine treatment at a dose of $5 \mathrm{mg} / \mathrm{kg}$ s.c. reversed the rotenone inhibition of ovulation. The results suggest that an increase in mitochondrial respiration is an essential feature of the ovulation process in mammals.
\end{abstract}

\section{Introduction}

There are reports of an increase in the size and number of mitochondria in the granulosa cells of mammalian ovarian follicles which have been stimulated by an ovulatory dose of gonadotrophin (Bjersing \& Cajander, 1974; Mori et al., 1979). There is also evidence that gonadotrophins induce an increase in cytochrome oxidase activity in rabbit granulosa cells (Koshida et al., 1984). Together, this information suggests that an elevation in mitochondrial oxidation in granulosa cells may be an important aspect of the ovulation process.

The objective of the present study was to determine whether an increase in cytochrome oxidase activity in ovarian follicles is essential for ovulation.

\section{Materials and Methods}

Animals. Wistar rats were purchased from a commercial breeding company (Shimizu Experimental Animal Co., Kyoto, Japan). These immature females (21 days of age) were exposed to a 14-h daily light period which began at 07:00 h. The animals received food and water ad libitum. At 09:00 h on Day 24 of age, the animals were given an i.p. injection of 10 i.u. PMSG (Teikokuhormone Mfg. Co. Ltd, Tokyo, Japan) in 0.1 ml saline (9 $\mathrm{g} \mathrm{NaCl} / 1)$. At 09:00 h on Day 26, ovulation was induced by an i.p. injection of 5 i.u. hCG (Mochida Pharmacological Corp., Tokyo, Japan). From our experience, immature rats treated in this manner begin to ovulate at $12-14 \mathrm{~h}$ after $\mathrm{hCG}$.

Ovulation rate. At $24 \mathrm{~h}$ after the administration of hCG, or rotenone i.p. at same time as hCG, the rats were killed by overexposure to ethyl ether vapour. (The rotenone, thyroxine and steroids which were tested were all obtained from Sigma Chemical Co., St Louis, MO, U.S.A.) The oviducts were separated from the ovaries and placed on a microscope slide. These isolated oviducts were flattened by a second microscope slide and then examined under a dissecting microscope with substage illumination. The numbers of ova were counted in each pair of oviducts to determine the ovulation rate for each rat.

Cytochrome axidase activity. Ovaries were weighed wet, homogenized for $15 \mathrm{sec}$ in $0.01 \mathrm{M}$-phosphate buffer $(0 \cdot 1 \mathrm{ml}$ of $\mathrm{pH} 7.0$ buffer per $1.0 \mathrm{mg}$ ovarian tissue) by a polytrone homogenizer, and centrifuged at $1000 \mathrm{~g}$ for $10 \mathrm{~min}$. Cytochrome oxidase activity was determined by a spectrophotometric method (Smith, 1955), which measured the rate of oxidation of reduced cytochrome $c$ by aliquants of the ovarian extract. The rate of oxidation of reduced cytochrome $c$ 
is determined by measuring spectrophotometrically the decrease in absorbance at $550 \mathrm{~nm}$ as the reduced cytochrome $c$ is oxidized, since the peak of the $\alpha$-band of the absorption spectrum of reduced cytochrome $c$ is at $550 \mathrm{~nm}$. The activity was expressed as nmol cytochrome oxidized $/ \mathrm{min} / \mathrm{mg}$ tissue.

Steroid concentrations. For steroid determinations, blood was obtained from the vena cava and the plasma samples were stored at $-20^{\circ} \mathrm{C}$ until they were assayed by a previously described procedure (Mori et al., 1980).

Statistical analysis. The differences between experimental groups were determined by Student's $t$ test. In all cases, the level of significance was taken as $P \leqslant 0.05$.

\section{Results}

\section{Effect of rotenone on ovulation}

Administration of rotenone at the same time as hCG in doses of $0.125,0.25$ and $0.5 \mathrm{mg} / \mathrm{kg}$, resulted in inhibition of ovulation that was proportional to the dose of rotenone (Table 1). The maximum dose of $0.5 \mathrm{mg}$ rotenone $/ \mathrm{kg}$ blocked ovulation almost completely.

Table 1. Effect of rotenone on ovulation in rats

\begin{tabular}{lccc}
\hline Treatment & No. of rats & Ovulating rats & Ova/rat \\
\hline Control & 17 & $17(100 \%)$ & $43 \cdot 5 \pm 0 \cdot 36$ \\
Rotenone $(0.125 \mathrm{mg} / \mathrm{kg})$ & 11 & $11(100 \%)$ & $24 \cdot 0 \pm 3.08^{*}$ \\
Rotenone $(0.25 \mathrm{mg} / \mathrm{kg})$ & 15 & $10(67 \%)$ & $8 \cdot 0 \pm 0.88^{*}$ \\
Rotenone $(0.50 \mathrm{mg} / \mathrm{kg})$ & 10 & $3(30 \%)$ & $1 \cdot 5 \pm 0.44^{*}$ \\
\hline
\end{tabular}

* $P<0.001$ compared with control value.

Table 2. Effect of rotenone on rat ovarian cytochrome oxidase after hCG

\begin{tabular}{|c|c|c|c|}
\hline Treatment & $\begin{array}{c}\text { Time after hCG } \\
\text { (h) }\end{array}$ & No. of rats & $\begin{array}{c}\text { Cytochrome } \\
\text { oxidase activity } \\
\text { (nmol/min } / \mathrm{mg} \text { tissue) }\end{array}$ \\
\hline Control & 0 & 10 & $5.03 \pm 0.54$ \\
\hline Control & 3 & 10 & $6.62 \pm 0.44^{*}$ \\
\hline Control & 6 & 8 & $13 \cdot 10 \pm 2 \cdot 68^{* *}$ \\
\hline Control & 9 & 12 & $7.57 \pm 0.46^{* *}$ \\
\hline Control & 12 & 10 & $8.81 \pm 0.54^{* * *}$ \\
\hline Rotenone $(0.5 \mathrm{mg} / \mathrm{kg})$ & 3 & 10 & $4.05 \pm 0.45 t$ \\
\hline Rotenone $(0.5 \mathrm{mg} / \mathrm{kg})$ & 6 & 8 & $8.14 \pm 0.57 \dagger$ \\
\hline Rotenone $(0.5 \mathrm{mg} / \mathrm{kg})$ & 12 & 6 & $6.57 \pm 0.91 \dagger$ \\
\hline
\end{tabular}

${ }^{*} P<0.05 ;{ }^{* *} P<0.01 ; * * * P<0.001$ compared with 0 -h control.

$\dagger P<0.05 ;+P<0.001$ compared with control at same time.

Table 3. Effect of rotenone on plasma progesterone, oestradiol and testosterone concentrations (mean \pm s.e.m.) in rats after $h C G$

\begin{tabular}{lccccc}
\hline Treatment & Hours after hCG & No. of rats & $\begin{array}{c}\text { Progesterone } \\
(\mathrm{ng} / \mathrm{ml})\end{array}$ & $\begin{array}{c}\text { Oestradiol } \\
(\mathrm{pg} / \mathrm{ml})\end{array}$ & $\begin{array}{c}\text { Testosterone } \\
(\mathrm{ng} / \mathrm{ml})\end{array}$ \\
\hline Control & 0 & 13 & $17 \cdot 3 \pm 0 \cdot 55$ & $421 \cdot 0 \pm 35 \cdot 25$ & $1 \cdot 50 \pm 0 \cdot 09$ \\
Control & 4 & 10 & $84 \cdot 2 \pm 7 \cdot 49^{*}$ & $341 \cdot 2 \pm 33 \cdot 20$ & $1 \cdot 54 \pm 0 \cdot 11$ \\
Control & 9 & 13 & $63 \cdot 2 \pm 2 \cdot 26^{*}$ & $271 \cdot 0 \pm 24 \cdot 46$ & $0 \cdot 97 \pm 0 \cdot 06$ \\
Rotenone $(0 \cdot 5 \mathrm{mg} / \mathrm{kg})$ & 4 & 6 & $44 \cdot 6 \pm 5 \cdot 27 \dagger$ & $219 \cdot 9 \pm 36 \cdot 01$ & $1 \cdot 28 \pm 0 \cdot 28$ \\
Rotenone $(0 \cdot 5 \mathrm{mg} / \mathrm{kg})$ & 9 & 6 & $31 \cdot 7 \pm 5 \cdot 27^{\dagger}$ & $401 \cdot 6 \pm 57 \cdot 60$ & $1 \cdot 51 \pm 0 \cdot 37$ \\
\hline
\end{tabular}

$* P<0.01$ compared with 0 -h control.

$\uparrow P<0.05$ compared with control at same time. 
Table 4. Effect of progesterone and thyroxine on rotenone-blocked ovulation in rats

\begin{tabular}{|c|c|c|c|}
\hline Treatment & No. of rats & Ovulating rats & Ova/rat \\
\hline Control & 17 & $17(100 \%)$ & $43.5 \pm 0.36$ \\
\hline Rotenone $(0.25 \mathrm{mg} / \mathrm{kg})$ & 15 & $10(67 \%)$ & $8 \cdot 0 \pm 0 \cdot 88$ \\
\hline $\begin{array}{l}\text { + progesterone }(4 \mathrm{mg} / \mathrm{kg}) \\
\text { Rotenone }(0.25 \mathrm{mg} / \mathrm{kg})\end{array}$ & 12 & $9 \quad(75 \%)$ & $8 \cdot 2 \pm 2 \cdot 28$ \\
\hline+ thyroxine $(5 \mathrm{mg} / \mathrm{kg})$ & 8 & $8(100 \%)$ & $44 \cdot 4 \pm 1 \cdot 77$ \\
\hline
\end{tabular}

\section{Effect of rotenone on ovarian cytochrome oxidase activity}

Cytochrome oxidase activity increased significantly within $3 \mathrm{~h}$ after hCG (Table 2). The most activity was measured at $6 \mathrm{~h}$ after hCG, when it was $2 \cdot 6$-fold greater than the control level. In parallel groups of animals which recieved $0.5 \mathrm{mg}$ rotenone $/ \mathrm{kg}$, the cytochrome oxidase activity was significantly reduced.

\section{Effect of rotenone on plasma concentrations of ovarian steroids}

By $4 \mathrm{~h}$ after hCG, there was a 5-fold increase in progesterone, and values remained significantly elevated at $9 \mathrm{~h}$ after hCG (Table 3). Concentrations of oestradiol and testosterone were essentially unchanged, or slightly lower, at 4 and $9 \mathrm{~h}$ after hCG. The increase in progesterone at these times was suppressed if $0.5 \mathrm{mg}$ rotenone $/ \mathrm{kg}$ was administered at the same time as hCG.

\section{Reversal of rotenone-blocked ovulation by thyroxine}

Thyroxine treatment $(5 \mathrm{mg} / \mathrm{kg})$ completely reversed the inhibitory effect of rotenone on ovulation (Table 4). On the other hand, progesterone at a dose of $4 \mathrm{mg} / \mathrm{kg}$ did not alter the blockage of ovulation by rotenone.

\section{Discussion}

The present biochemical measurement of an increase in ovarian cytochrome oxidase activity is in agreement with our previous histochemical detection of an increase in cytochrome oxidase and succinate dehydrogenase in rabbit granulosa cells at $3 \mathrm{~h}$ after hCG stimulation of ovulation (Koshida et al., 1984). Together, these data support the hypothesis that an elevation in mitochondrial oxidation within the granulosa layer of ovulatory follicles is an important part of the ovulatory process.

The rotenone which we tested is well known as a potent inhibitor of mitochondrial respiration (Öberg, 1961). This agent reportedly acts within the respiratory sequence at the electron transfer step between diphosphopyridine nucleotide and flavin (Lindahl \& Öberg, 1961). Therefore, we anticipated that the administration of rotenone to PMSG/hCG-treated immature rats would decrease mitochondrial oxidation and energy production in preovulatory follicles. This expectation was verified by the measurable decrease in ovarian cytochrome oxidase and ovulation after rotenone treatment. Experiments with rabbits (unpublished) showed that rotenone still inhibited hCG-induced ovulation even when the hCG was given through the ear vein, indicating that the simultaneous administration of hCG and rotenone by the same route in the present experiments with rats was unlikely to lead to blocking of the ability of hCG to induce ovulation.

Thyroxine increases oxygen consumption and calorigenesis in animal tissues (Barker \& Klitgaard, 
1952). This metabolic effect is due to its stimulation of mitochondrial oxidation (Hoch, 1962). We therefore administered thyroxine to see whether it could reverse the rotenone blockage of ovulation. Its positive action is presumably the result of stimulation of the citric acid cycle in the granulosa layer of the follicle. In any event, the results suggest that normal thyroid metabolism may be important for ovulation. This deduction is supported indirectly by evidence that thyroidectomy inhibits ovulation in rabbits (Thorsoe, 1962) and that hypothyroidic women suffer oligomenorrhoea and anovulation (Ingbar, 1985).

The results of this study show that rotenone inhibited progesterone synthesis in ovulatory follicles. This suggests that ovarian steroidogenesis is also dependent on mitochondrial respiration. The conversion of cholesterol into progestagens is proportional to the concentration of NADH generated by the citric acid cycle (Uzgiris et al., 1971). Therefore, the depression of progesterone production by rotenone could be due to interference with the generation of NADH by the citric acid cycle, and, ultimately, to a reduction in the synthesis of ATP. We believe that these energetic agents may contribute to the neosynthesis of steroidogenic enzymes, since we have histological evidence which shows that rotenone suppresses an hCG-induced increase in $3 \beta$-hydroxysteroid dehydrogenase activity in the granulosa layer of mature rabbit follicles (Koshida et al., 1986).

The failure of progesterone treatment to reverse the rotenone blockage of ovulation could be interpreted to mean that progesterone is not an essential factor in the ovulatory process. However, there is circumstantial evidence to suggest that progesterone is involved in some way in ovulation. For example, the administration of antiprogesterone to PMSG/hCG-treated immature rats has been shown to inhibit ovulation, and this inhibition could be reversed by treating the animals with progesterone (Mori et al., 1977). Therefore, it may be that the rotenone-induced suppression of mitochondrial respiration in the follicles is interfering with some other important metabolic events within the ovulation process which occur subsequent to steroidogenesis, and therefore which cannot be restored simply by progesterone treatment.

Ultimately, the ovulation process leads to degradation of the collagenous connective tissue in the wall of a Graafian follicle (Espey, 1967; Okamura et al., 1980). This collagen degradation is thought to be due to de-novo synthesis and/or activation of proteolytic enzymes (Espey, 1974; Fukumoto $e t$ al., 1981). Therefore, it may be that rotenone also suppresses the activity of this enzyme. Rotenone inhibits the preovulatory increase in ovarian proteolytic activity and subsequent degradation of mature follicles in hCG-stimulated rabbits (unpublished observations).

These findings suggest that an elevation in mitochondrial respiration in preovulatory follicles is an indispensable aspect of ovarian steroid synthesis and ovulation.

We thank Professor L. L. Espey, Biology Department, Trinity University, San Antonio, Texas, for his critical reading and revision of this manuscript.

\section{References}

Barker, S.B. \& Klitgaard, H.M. (1952) Metabolism of tissues excited from thyroxine-injected rats. Am. J. Physiol. 170, 81-86.

Bjersing, L. \& Cajander, S. (1974) Ovulation and the mechanism of follicle rupture. VI. Ultrastructure of membrana granulosa of rabbit graafian follicles prior to induced ovulation. Cell Tiss. Res. 153, I-4.

Espey, L.L. (1967) Ultrastructure of the apex of the rabbit graafian follicle during the ovulatory process. Endocrinology 81, 267-276.

Espey, L.L. (1974) Ovarian proteolytic enzymes and ovulation. Biol. Reprod. 10, 216-235.

Fukumoto, M., Yajima, Y., Okamura, H. \& Midorikawa, o. (1981) Collagenolytic enzyme activity in human ovary: an ovulatory enzyme system. Fert. Steril. 36, $746-750$.

Hoch, F. (1962) Biochemical actions of thyroid hormones. Physiol. Rev. 42, 605-673.

Ingbar, S.H. (1985) The thyroid gland. In Textbook of Endocrinology, 7th edn, pp. 698-815. Eds J. D. Wilson \& D. W. Foster. W. B. Saunders Company, Philadelphia.

Koshida, M., Takenaka, A., Kanzaki, H., Takemori, K. \& Okamura, H. (1984) A histochemical study of the respiratory system in rabbit ovarian follicles during ovulation. Acta obstet. gynaec. jap. 36, 359-362.

Koshida, M., Okamura, H., Mori, T. \& Takenaka, A. (1986) Effect of rotenone on rabbit ovulation and 
histochemical activities of cytochrome oxidase and $3 \beta$-hydroxysteroid dehydrogenase of the follicle. Acta obstet. gynaec. jap. 38, 1741-1746.

Lindahl, P.E. \& Obberg, K.E. (1961) The effect of rotenone on respiration and its point of attack. Expl Cell Res. 23, 228-237.

Mori, T., Suzuki, A., Nishimura, T. \& Kambegawa, A. (1977) Inhibition of ovulation in immature rats by anti-progesterone antiserum. $J$. Endocr. 73, 185-186

Mori, T.; Takenaka, A., Yoshida, Y., Suzuki, A., Fujita, Y. \& Nishimura, T. (1979) Preovulatory changes in morphology of rabbit ovarian follicles. Endocrinol. japon. 26, 379-388.

Mori, T., Kohda, H., Kinoshita, Y., Ezaki, Y., Morimoto, N. \& Nishimura, T. (1980) Inhibition by indomethacin of ovulation induced by human chorionic gonadotropin in immature rats primed with pregnant mare serum gonadotropin. J. Endocr. 84, 333-341.

Oberg, K.E. (1961) The site of the action of rotenone in the respiratory chain. Expl Cell Res. 24, 163-164.
Okamura, H., Takenaka, A., Yajima, Y. \& Nishimura, T. (1980) Ovulatory changes in the wall at the apex of the human Graafian follicle. J. Reprod. Fert. 58, $153-155$.

Smith, L. (1955) Spectrophotometric assay of cytochrome c oxidase. In Methods of Biochemical Analysis, vol. II, pp. 427-434. Ed. D. Glick. Interscience, New York.

Thorsoe, H. (1962) Inhibition of ovulation and changes in ovarian mucopolysaccharides induced by thyroidectomy in rabbits. Acta endocr., Copenh. 41, 441-447.

Uzgiris, V.I., McIntosh, E.N., Alonso, C. \& Salhanic, H.A. (1971) Role of reversed electron transport in bovine corpus luteum mitochondrial steroid synthesis. Biochemistry. N.Y. 10, 2916-2922.

Received 2 June 1986 